\title{
Stimulation of motility and respiration of intact fowl spermatozoa by calyculin A, a specific inhibitor of protein phosphatase-1 and $-2 \mathrm{~A}$, via a $\mathrm{Ca}^{2+}$-dependent mechanism
}

\author{
K. Ashizawa, A. Magome and Y. Tsuzuki \\ Laboratory of Animal Reproduction, Faculty of Agriculture, Miyazaki University, Miyazaki 889-21, \\ Japan
}

\begin{abstract}
Intact fowl spermatozoa became almost immotile at $40^{\circ} \mathrm{C}$. In contrast, the presence of 10-1000 nmol calyculin $\mathrm{A} \mathrm{I}^{-1}$, a specific inhibitor of protein phosphatase-1 (PP1) and -2A (PP2A), permitted activation of sperm motility in a dose-dependent manner. Calyculin $\mathrm{A}$ also stimulated the rate of oxygen consumption by spermatozoa, and induced a concomitant decrease in ATP concentrations, suggesting a coupling of ATP hydrolysis to the rate of oxidative phosphorylation. However, the motility and oxygen consumption of spermatozoa loaded with an intracellular $\mathrm{Ca}^{2+}$ chelator, 1,2-bis (2-aminophenoxy)ethane- $N, N, N^{\prime}, N^{\prime}$ tetraacetic acid, tetraacetoxymethyl ester (BAPTA/AM), were not stimulated by calyculin $A$ alone, but only after the subsequent addition of $2 \mathrm{mmol} \mathrm{CaCl} \mathrm{Cl}^{-1}$. These results suggest that inhibition of the activities of endogenous PP1 and PP2A may stimulate the motility and metabolic activity of fowl spermatozoa at $40^{\circ} \mathrm{C}$ via a mechanism that requires intracellular free $\mathrm{Ca}^{2+}$.
\end{abstract}

\section{Introduction}

Unlike mammalian spermatozoa, fowl spermatozoa show definitive temperature-dependent changes in their motility. In most synthetic diluents, they become immotile at the avian body temperature of $40-42^{\circ} \mathrm{C}$, and motility is restored by decreasing the temperature (Munro, 1938; Ashizawa and Nishiyama, 1978; Takeda, 1982; Ashizawa and Okauchi, 1984; Wishart and Ashizawa, 1987; Ashizawa ef al., 1989a, b; Thomson and Wishart, 1989, 1991; Ashizawa et al., 1992a). Munro (1938) suggested that avian spermatozoa may be immotile during most of their sojourn in the female reproductive tract. This view is supported by the observation that in the uterovaginal sperm storage tubules, where avian spermatozoa can remain for several weeks before fertilization, spermatozoa appear to be immotile (Bakst, 1987). This immotility may be useful for the prolonged survival of spermatozoa in the tubules (Ashizawa and Nishiyama, 1978). In addition, sperm motility does not seem to be required in domestic hens for the movement of spermatozoa within the oviduct from the shell gland (uterus) to the magnum, as dead spermatozoa or carbon powder inserted in the shell gland are transported along the reproductive tract (Mimura, 1939). However, it has been shown that only motile spermatozoa can traverse from the posterior to the anterior vagina (Takeda, 1974), and it has been suggested that factors within seminal plasma, deposited with the spermatozoa, may enhance intravaginal sperm transport (Terada ef al., 1984). Two factors that stimulate sperm motility at $40^{\circ} \mathrm{C}, \mathrm{Ca}^{2+}$ and an unidentified regulator of low $M_{\mathrm{r}}$, have

Received 22 March 1995. been identified in seminal plasma (Ashizawa and Wishart, 1987). Furthermore, Ashizawa and Wishart (1992) demonstrated that the fluid that collects in the ovarian pocket at the time of ovulation contains factors similar to those found in seminal plasma, and suggested that the sperm motilitystimulating factors may be implicated in promoting fertilization in domestic hens even at $40^{\circ} \mathrm{C}$.

In addition to such extracellular stimulating signals, reversible phosphorylation of intracellular proteins on serine, threonine and tyrosine residues by protein kinases and phosphatases is widely accepted as a principal mechanism by which eukaryotic cells respond to extracellular signals. Many protein kinases and phosphatases have multiple substrates in vivo, enabling a diversity of responses to these extracellular stimuli (for a review, see Cohen, 1989; Holmes and Boland, 1993; Hubbard and Cohen, 1993). With regard to sperm motility, protein phosphorylation by cAMP-dependent protein kinase seems to play a primary role in the second messenger regulatory mechanisms of flagellar axoneme-based movement in a variety of species except fowl (for a review, see Tash and Means, 1983; Brokaw, 1987; Lindemann and Kanous, 1989; Majumder $e t$ al., 1990; Mohri, 1993; Morisawa, 1994).

However, a new generation of protein phosphatase inhibitors, such as okadaic acid and calyculin A, isolated from various microorganisms, have proved extremely useful for understanding the role of protein dephosphorylation by phosphatases (Cohen et al., 1990). For example, it has been demonstrated that the contraction of chemically skinned smooth muscle fibres is enhanced by the addition of okadaic acid or calyculin A (Ozaki et al., 1987a, b; Takai et al., 1987; Suzuki and Itoh, 1993), although calyculin A is effective at 
lower concentrations than is okadaic acid (Hartshorne et al., 1989). Since calyculin $A$ has a potency similar to that of okadaic acid as an inhibitor of protein phosphatase-2A (PP2A), but is $10-100$ times more effective as an inhibitor of protein phosphatase-1 (PPI) (Ishihara et al., 1989a), it is suggested that PP1 is a major myosin phosphatase in vivo (Cohen, 1989).

The treatment of human spermatozoa with calyculin $A$ allows them to undergo the acrosome reaction sooner, suggesting that dephosphorylation by protein phosphatases, probably PP1, may be involved in the regulation of capacitation (Furuya et al., 1993). Furthermore, it has been proposed that PPI may be a dominant regulator for temperature-dependent flagellar movement of fowl spermatozoa since, in addition to calyculin $A$ and okadaic acid, inhibitors 1 and 2 , which are specific inhibitor proteins of PP1 (Cohen, 1989), also stimulate the motility of demembranated spermatozoa at $40^{\circ} \mathrm{C}$ (Ashizawa et al., 1994a). However, limited information is available concerning the effects of PP1 and PP2A on the metabolic activity of spermatozoa, or that of other cells such as smooth muscle.

In the following experiment, therefore, attempts were made to investigate the effects of calyculin $\mathrm{A}$, a specific inhibitor of PPI and PP2A, on the motility, metabolic activity and $\mathrm{Ca}^{2+}$ flux of intact fowl spermatozoa.

\section{Materials and Methods}

\section{Animals and preparation of spermatozoa}

Commerical White Leghorn roosters (Babcock strain, Akagi Poultry Breeding Farm, Miyazaki) were used throughout the study. All birds were housed in individual cages and fed ad libitum on a commercial breeder diet. They were exposed to a photoperiod of $14 \mathrm{~h}$ light:10 $\mathrm{h}$ dark.

Semen was collected by the method of Bogdonoff and Shaffner (1954). Samples of semen pooled from four to six males were diluted approximately tenfold in $150 \mathrm{mmol}$ $\mathrm{NaCl} \mathrm{I}^{-1}$ with $20 \mathrm{mmol}$ TES ( $N$-Tris-[hydroxymethyl]-methyl2-aminoethanesulfonic acid) $1^{-1}$ at $\mathrm{pH} 7.4$ and centrifuged at $700 \mathrm{~g}$ for $13 \mathrm{~min}$ at room temperature $\left(20-25^{\circ} \mathrm{C}\right.$ ). The washed spermatozoa were reconstituted in the same buffer to give a final concentration of approximately $1 \times 10^{9}$ cells $\mathrm{ml}^{-1}$. Samples of 3-4 ml were poured into $30 \mathrm{ml}$ Erlenmeyer flasks with a screw cap.

\section{Chemicals}

Calyculin A was purchased from Wako Pure Chemical Industries, Ltd (Osaka) 1-(2-(5"-carboxyoxazol-2"-yl)6-aminobenzofuran-5-oxy)-2-( $2^{\prime}$ - amino- $5^{\prime}$-methylphenoxy)ethane- $N, N, N^{\prime}, N^{\prime}$-tetraacetic acid pentaacetoxymethyl ester (fura-2/AM) and 1, 2-bis (2-aminophenoxy) ethane- $N, N, N^{\prime}, N^{\prime}$ tetraacetic acid, tetraacetoxymethyl ester (BAPTA/AM) was obtained from Dojindo Laboratories Inc. (Kumamoto). Adenosine 5'-triphosphate (ATP), Cremophor EL, TES, Triton $X-100$ and desiccated firefly tails were purchased from Sigma Chemical Co. (St Louis, MO). Other chemicals were of reagent grade from Nacalai Tesque Inc. (Kyoto).

\section{Analysis of sperm motility}

Sperm samples were preincubated aerobically in a shaking water bath at $40^{\circ} \mathrm{C}$ for $10 \mathrm{~min}$. The dose-response relationship of motility of intact spermatozoa in TES-NaCl buffer was then measured at $40^{\circ} \mathrm{C}$ after the addition of various concentrations of calyculin A. The suspension of spermatozoa was placed in a microscope chamber (Sekisui Chemical Co., Tokyo, UR-157 type, $0.07 \mathrm{~mm}$ in depth) $25 \mathrm{~min}$ after the start of incubation, and the motility of spermatozoa was recorded by videomicroscopy (magnification on the 12-inch black and white monitor was approximately $\times 600$ ) at $40^{\circ} \mathrm{C}$ on a thermostatically controlled warm plate (Katz and Overstreet, 1981). Measurements to determine the percentage motility were made on 200-300 spermatozoa, distributed uniformly among the three or more fields.

For BAPTA/AM-treated experiments, intact spermatozoa were loaded with BAPTA/AM by the methods described by Ashizawa et al. (1994b). Briefly, sperm suspension $(0.1 \mathrm{ml})$ was added to $1 \mathrm{mI}$ BAPTA/AM solution and shaken for $90 \mathrm{~min}$ at room temperature $\left(20-25^{\circ} \mathrm{C}\right)$ in the dark. During this incubation, final concentrations of BAPTA/AM and spermatozoa were about $90 \mu \mathrm{mol} \mathrm{I} I^{-1}$ and $0.9 \times 10^{8} \mathrm{ml}^{-1}$, respectively. Sperm preparations diluted with TES- $\mathrm{NaCl}$ buffer to the same concentrations described above and shaken for $90 \mathrm{~min}$ at room temperature were used as controls. After the $10 \mathrm{~min}$ preincubation at $40^{\circ} \mathrm{C}$, the sperm preparations with or without BAPTA/AM treatment were incubated aerobically in a shaking water bath at $40^{\circ} \mathrm{C}$. At 3 and $15 \mathrm{~min}$ after the start of incubation, $500 \mathrm{nmol}$ calyculin $\mathrm{A} \mathrm{I}^{-1}$ and $2 \mathrm{mmol} \mathrm{CaCl}_{2} \mathrm{I}^{-1}$ were added, respectively. During incubation of spermatozoa, the motility was assayed as described above.

\section{Analysis of oxygen consumption and ATP concentrations}

The oxygen consumption of spermatozoa was determined polarographically with a Clark electrode by the method of Kielley (1963), using a YSI model 53 biological oxygen monitor (Yellow Springs Instrument Co., Yellow Springs, OH). The rate of oxygen consumption was expressed in terms of $\mu \mathrm{I}_{2}$ consumption $10^{-8}$ spermatozoa $\mathrm{h}^{-1}$. Numbers of spermatozoa were estimated by the method of Wishart and Ross (1985), using a double-beam spectrophotometer (Shimadzu, Model UV-150-02, Kyoto).

The ATP concentration in spermatozoa was assayed by firefly bioluminescence in a boiled extract (Wishart, 1982).

\section{Analysis of intracellular free $\mathrm{Ca}^{2+}$ concentrations}

Determination of the intracellular free $\mathrm{Ca}^{2+}$ concentrations was carried out with the fluorescent indicator Fura-2, essentially according to Grynkiewicz et al. (1985), but with some modifications (Ashizawa et al., 1992b). Fluorescence intensity was measured with a dual-wavelength spectrofluorometer (Shimadzu, Model RF-5000, Kyoto) with the sample chamber regulated at $30^{\circ} \mathrm{C}$ or $40^{\circ} \mathrm{C}$ by a circulating water jacket, and the sperm suspension was mixed continuously with a magnetic stirring bar. For the measurement of intracellular free $\mathrm{Ca}^{2+}$ concentrations, the excitation wavelength was set to 340 and $380 \mathrm{~nm}$, and the emission wavelength was set to $500 \mathrm{~nm}$. The 
ratio $(340: 380 \mathrm{~nm})$ of fluorescence intensity was monitored continuously. The calculation of intracellular free $\mathrm{Ca}^{2+}$ was based upon the equation described by Grynkiewicz of al. (1985), where a dissociation constant $\left(K_{d}\right)$ was $224 \mathrm{nmol} \mathrm{I}^{-1}$.

\section{Statistical analysis}

Statistical comparisons were performed using Student's $t$ test.

\section{Results}

Effects of calyculin $A$ on the motility and metabolic activity of intact fowl spermatozoa

The motility of intact spermatozoa was markedly affected by the addition of calyculin $\mathrm{A}$ at $40^{\circ} \mathrm{C}$. As the concentration of calyculin A was increased, the motility was stimulated gradually and maximum motility was obtained at a concentration of $250 \mathrm{nmol} \mathrm{I}^{-1}$ (Fig. 1a).

As with the stimulation of motility, the rate of oxygen consumption also increased with increasing concentrations of calyculin A at $40^{\circ} \mathrm{C}$. Conversely, the ATP concentrations decreased gradually in a dose-dependent manner, suggesting that spermatozoa used endogenous ATP due to the initiation of motility (Fig. Ib).

Effects of calyculin $A$ on the motility and metabolic activity of BAPTAlAM-treated fowl spermatozoa

At $40^{\circ} \mathrm{C}$, neither control nor BAPTA/AM-treated spermatozoa were motile. The motility of control spermatozoa was restored by the addition of calyculin $\mathrm{A}$ alone. However, the motility of spermatozoa loaded with BAPTA/AM, an intracellular $\mathrm{Ca}^{2+}$ chelator, could not be restored even in the presence of calyculin $\mathrm{A}$ until the subsequent addition of $2 \mathrm{mmol} \mathrm{CaCl}{ }_{2} \mathrm{l}^{-1} 15 \mathrm{~min}$ after the start of incubation (Fig. 2a).

The concentration of ATP in control spermatozoa decreased significantly $(P<0.01)$ after the addition of calyculin A. In contrast, there was no significant decrease in BAPTA/AMtreated spermatozoa, but the concentration of ATP decreased slightly after the addition of $\mathrm{CaCl}_{2}$ (Fig. 2b).

The rates of oxygen consumption of spermatozoa treated or untreated with BAPTA/AM at $40^{\circ} \mathrm{C}$ were significantly different $(P<0.05) ; 3.6 \pm 0.3$ and $5.0 \pm 0.3 \mu \mathrm{l} \mathrm{O}_{2} 10^{-8}$ spermatozoa $\mathrm{h}^{-1}$, respectively. Furthermore, the rate of oxygen consumption of control preparations increased significantly $(P<0.01)$ after the addition of calyculin $\mathrm{A}$. In contrast, the oxygen consumption of BAPTA/AM-treated preparations could not be stimulated by the addition of calyculin $\mathrm{A}$ alone. However, the subsequent addition of $2 \mathrm{mmol} \mathrm{CaCl}_{2} \mathrm{l}^{-1}$ stimulated the oxygen consumption significantly $(P<0.01)$ compared with the value before the addition of calyculin $\mathrm{A}$ or $\mathrm{CaCl}_{2}$ (Fig. $2 \mathrm{c}$ ).

\section{Effects of calyculin $A$ on the intracellular free $\mathrm{Ca}^{2+}$ concentration of fowl spermatozoa}

Intracellular free $\mathrm{Ca}^{2+}$ concentrations, measured by means of a fluorescent $\mathrm{Ca}^{2+}$ indicator Fura-2, increased rapidly after the (a)

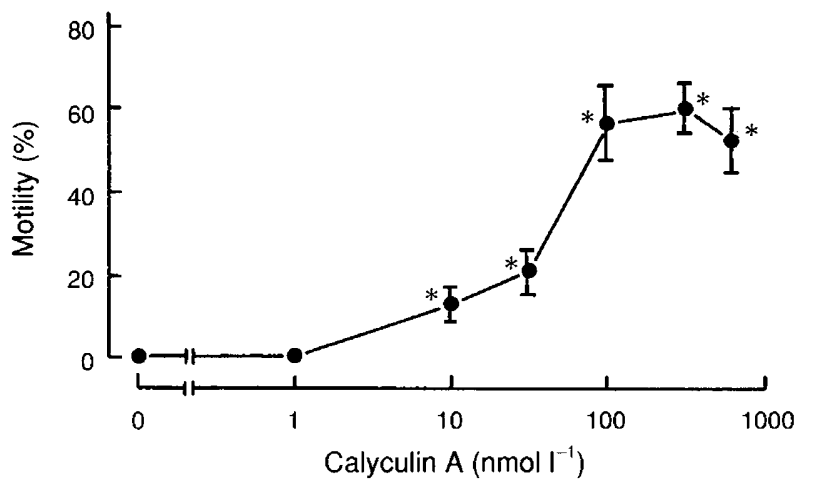

(b)

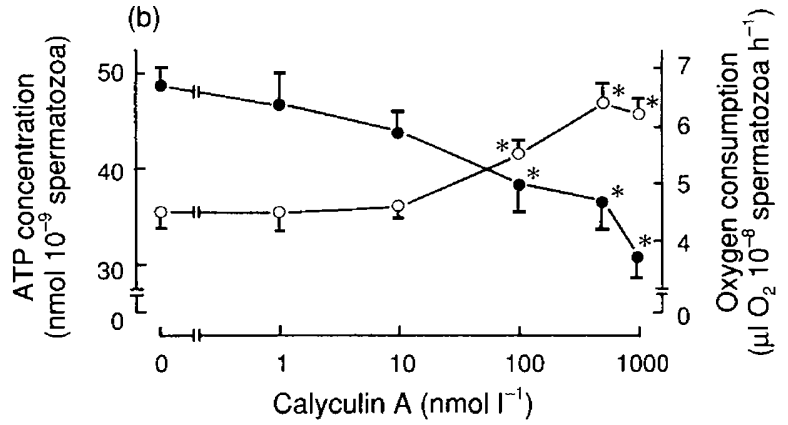

Fig. 1. (a) Motility and (b) oxygen consumption ( $\odot$ ) and ATP concentration ( ) of intact fowl spermatozoa after addition of various concentrations of calyculin $\mathrm{A}$ at $40^{\circ} \mathrm{C}$. Each point represents the mean ( \pm SEM) of five samples of spermatozoa. ${ }^{*} P<0.01$ compared with value at $0 \mathrm{nmol}^{-1}$ (control).

addition of $2 \mathrm{mmol} \mathrm{CaCl}_{2} \mathrm{I}^{-1}$ at $40^{\circ} \mathrm{C}$. Subsequently, the addition of calyculin $\mathrm{A}$ maintained almost the same $\mathrm{Ca}^{2+}$ concentration in the spermatozoa as that of the control (no addition of calyculin A) (Fig. 3a).

The intracellular free $\mathrm{Ca}^{2+}$ concentration of BAPTA/AMtreated spermatozoa before the addition of $\mathrm{CaCl}_{2}$ was almost $0 \mathrm{nmol} \mathrm{I}^{-1}$, even in the presence of calyculin A. However, the addition of $2 \mathrm{mmol} \mathrm{CaCl}_{2} \mathrm{l}^{-1}$ caused an influx of $\mathrm{Ca}^{2+}$ from the medium and the $\mathrm{Ca}^{2+}$ concentrations increased gradually (Fig. 3b).

\section{Discussion}

Generally, little information is available on the effects of PPI and PP2A on the metabolic activity of cells. In the present study, the presence of calyculin $\mathrm{A}$, a specific inhibitor of PP1 and $\mathrm{PP} 2 \mathrm{~A}$, stimulated the rate of oxygen consumption and the motility of intact fowl spermatozoa in a dose-dependent manner at $40^{\circ} \mathrm{C}$. These results suggest that inhibition of endogenous PP1 and PP2A activities stimulate the motility and respiration of fowl spermatozoa. Furthermore, it is assumed that the stimulation of respiration by calyculin A probably follows from the increase of motility, since calyculin A also stimulated the motility of demembranated spermatozoa at $40^{\circ} \mathrm{C}$ (Ashizawa et al., 1994a). Thus, the stimulatory effect of 
(a)
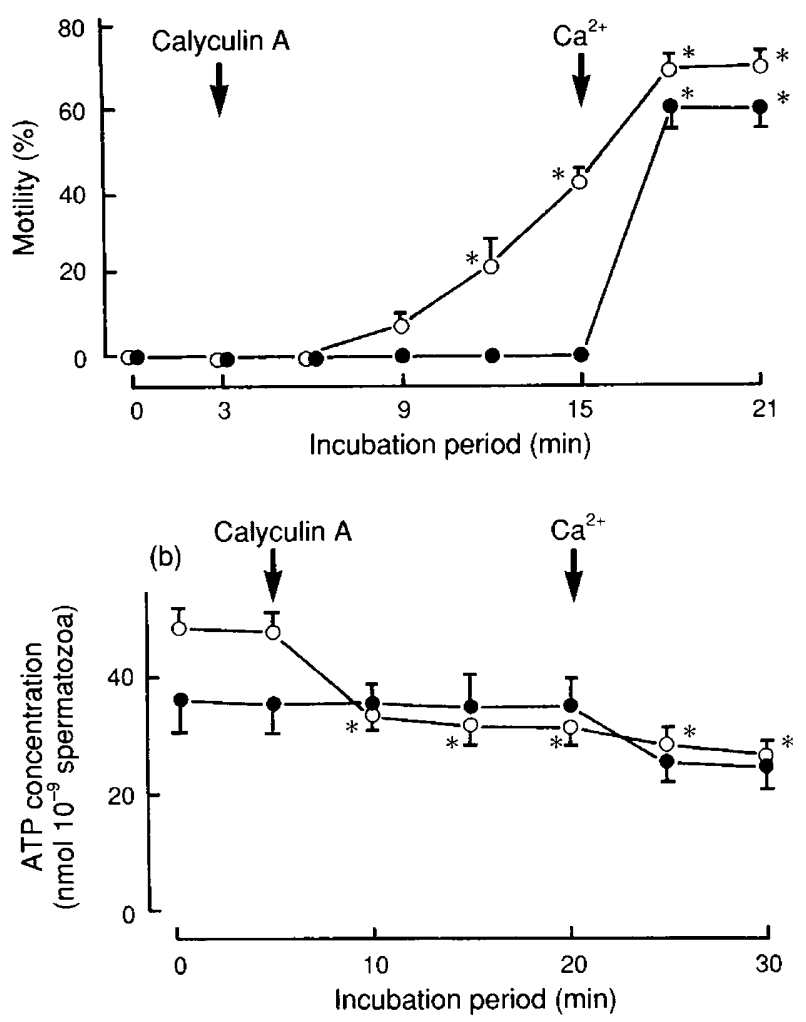

(c)

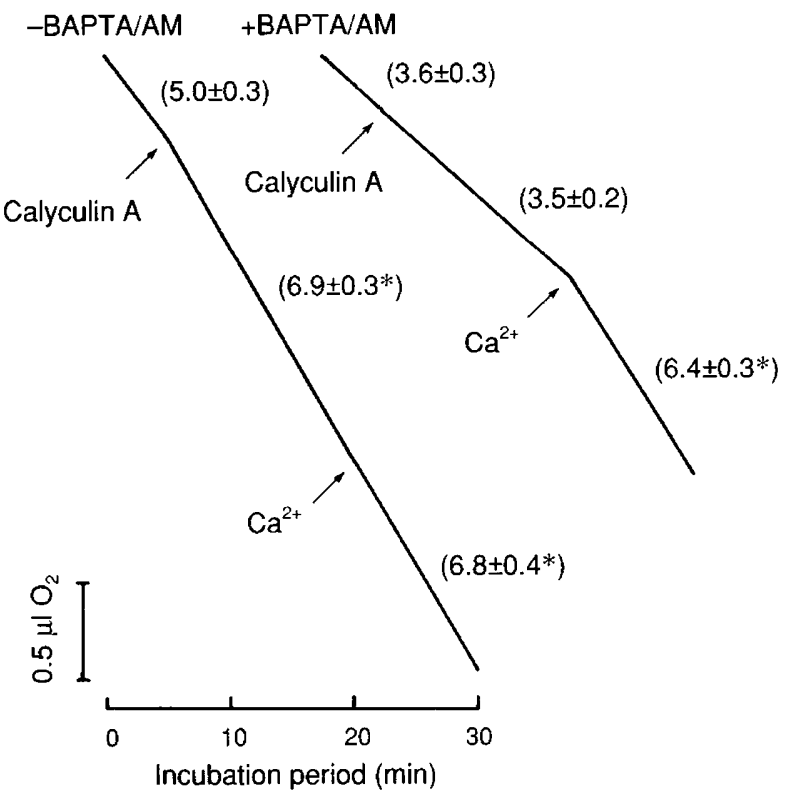

Fig. 2. (a) Motility and (b) ATP concentration of intact (b) and intracellular $\mathrm{Ca}^{2+}$ chelator BAPTA/AM-treated (•) fowl spermatozoa after addition (at arrows) of $500 \mathrm{nmol}$ calyculin $\mathrm{A}^{-1}$ and $2 \mathrm{mmol}$ $\mathrm{CaCl}_{2} \mathrm{1}^{-1}$ at $40^{\circ} \mathrm{C}$. Each point represents the mean ( $\pm \mathrm{SEM}$ ) of five samples of spermatozoa. ${ }^{*} P<0.01$ compared with value at 0 min. (c) Oxygen consumption ( $\mu \mathrm{l} \mathrm{O}_{2} 10^{-8}$ spermatozoa $\mathrm{h}^{-\mathrm{I}}$ ) of intact and BAPTA/AM-treated fowl spermatozoa at $40^{\circ} \mathrm{C}$ after addition of $500 \mathrm{nmol}$ calyculin $\mathrm{A} \mathrm{I}^{-1}$ and $2 \mathrm{mmol} \mathrm{CaCl}_{2} \mathrm{I}^{-1}$. Each value represents the mean ( $\pm \mathrm{SEM}$ ) of five samples of spermatozoa. ${ }^{*} P<0.01$ compared with value before the addition of calyculin $\mathrm{A}$. calyculin A on motility may be primarily the result of direct action on the axoneme, probably with coupling of ATP hydrolysis by the various types of ATPases (including dynein ATPase) to the rate of oxidative phosphorylation and respiration.

The motility and respiration of fowl spermatozoa are strongly influenced by their intracellular free $\mathrm{Ca}^{2+}$ concentrations (Thomson and Wishart, 1989, 1991; Ashizawa et al., 1992b, 1994b). The present study shows that calyculin A stimulated the motility and rate of oxygen consumption of control spermatozoa, but not spermatozoa loaded with the intracellular $\mathrm{Ca}^{2+}$ chelator, BAPTA/AM. However, the subsequent addition of $2 \mathrm{mmol} \mathrm{CaCl} \mathrm{I}^{-1}$ stimulated both parameters significantly $(P<0.01)$. Thus, it appears that calyculin A stimulates sperm motility via a $\mathrm{Ca}^{2+}$-dependent mechanism.

At the axonemal level, demembranated fowl spermatozoa, stimulated by calyculin $\mathrm{A}$ at $40^{\circ} \mathrm{C}$, lost their motility after the addition of $1 \mathrm{mmol} \mathrm{Ca}^{2+} \mathrm{l}^{-1}$ to the reactivation medium. When the $\mathrm{Ca}^{2+}$ concentration was varied from $10 \mathrm{nmol}$ to $100 \mu \mathrm{mol} \mathrm{l^{-1 }}$ by the subsequent addition of various concentrations of EGTA, motility was restored in inverse proportion to the $\mathrm{Ca}^{2+}$ concentration (Ashizawa et al., 1994a). Initially, it might seem likely that these results are inconsistent with those of intact spermatozoa described above. However, in the present work, the intracellular free $\mathrm{Ca}^{2+}$ concentration of intact fowl spermatozoa (measured by means of a fluorescent $\mathrm{Ca}^{2+}$ indicator, Fura-2) was approximately $50 \mathrm{nmol} \mathrm{I}^{-1}$ after the addition of calyculin A in BAPTA/AMuntreated spermatozoa, and maximally $200 \mathrm{nmol} \mathrm{l}^{-1}$ after the addition of both calyculin $\mathrm{A}$ and $\mathrm{Ca}^{2+}$ in BAPTA/AM-treated spermatozoa (Fig. 3b). These values were similar to those from preparations in which demembranated spermatozoa showed higher motility (Ashizawa et al., 1994a). Therefore, it is suggested that $\mathrm{Ca}^{2+}$ at nanomolar concentrations is necessary for the stimulation of motility induced by calyculin $\mathrm{A}$ in both intact and demembranated fowl spermatozoa, but such a stimulatory effect may not occur at zero or millimolar $\mathrm{Ca}^{2+}$ concentration.

It has been proposed that calyculin $\mathrm{A}$ is involved in the activation of the voltage-dependent $\mathrm{Ca}^{2+}$ channels in intact smooth muscle cells, although this effect appears to be independent of the calyculin A-induced contraction (Ishihara et al., 1989b). Klumpp et al. (1990) suggest that the voltagedependent $\mathrm{Ca}^{2+}$ channels on the ciliary membrane of the protozoan Paramecium are inactivated by a dephosphorylation event, and that okadaic acid blocks this dephosphorylation, inducing $\mathrm{Ca}^{2+}$ influx and the reversal of ciliary beat and initiating backward swimming. If there is such action in calyculin A or okadaic acid, intracellular free $\mathrm{Ca}^{2+}$ concentration should increase after the addition of such inhibitors. However, intracellular free $\mathrm{Ca}^{2+}$ concentration in fowl spermatozoa did not increase even in the presence of calyculin $\mathrm{A}$, compared with controls (Fig. 3a). A possible explanation for these results is that there is either an alternative mechanism in the regulation of $\mathrm{Ca}^{2+}$ channels of fowl spermatozoa or that both a $\mathrm{Ca}^{2+}$ ATPase-dependent pump system and $\mathrm{Ca}^{2+}$ channels are activated by calyculin $\mathrm{A}$, resulting in a balance of influx and efflux of $\mathrm{Ca}^{2+}$. Further investigations of $\mathrm{Ca}^{2+}$ mobilization are required. 


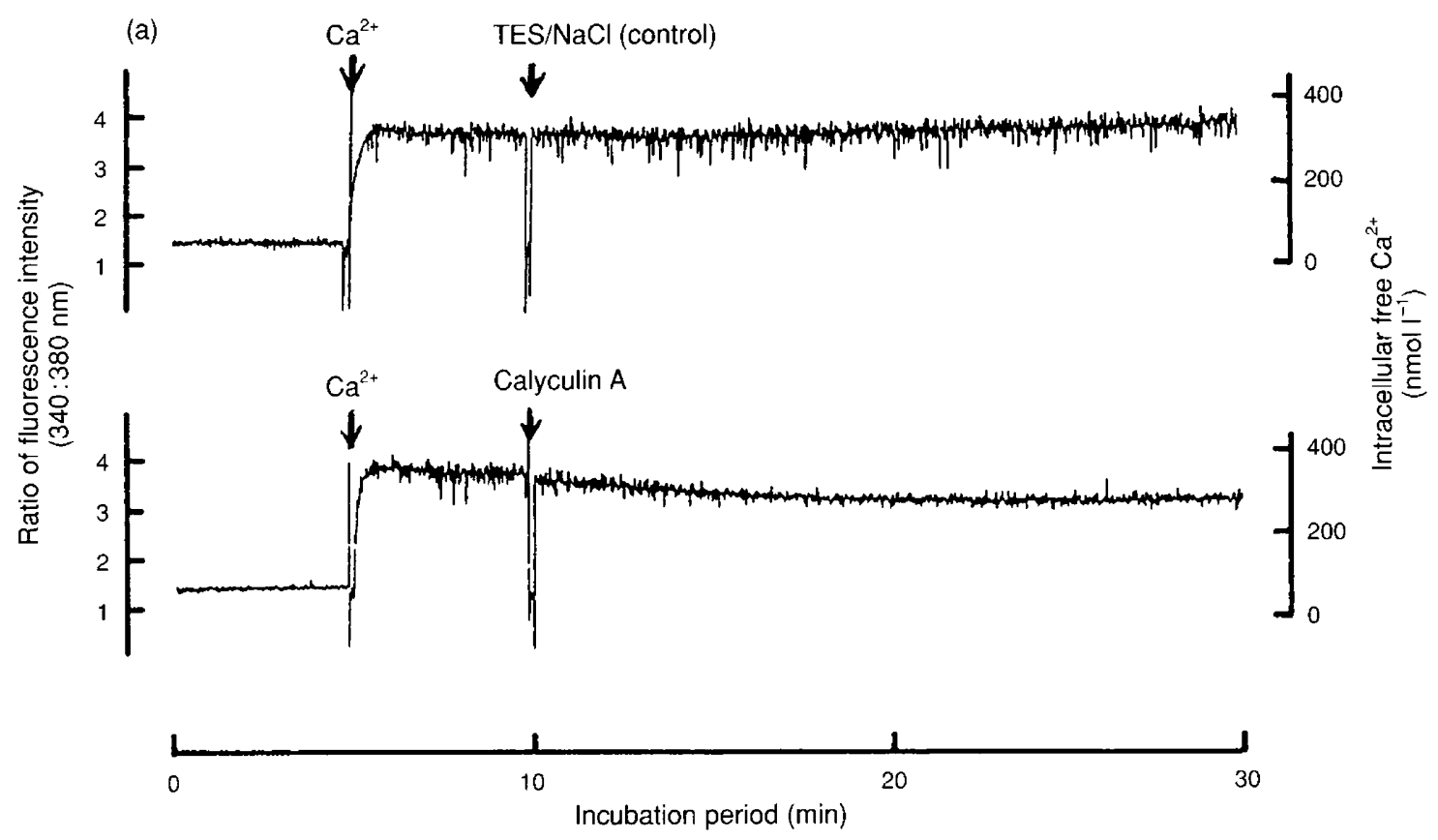

(b)

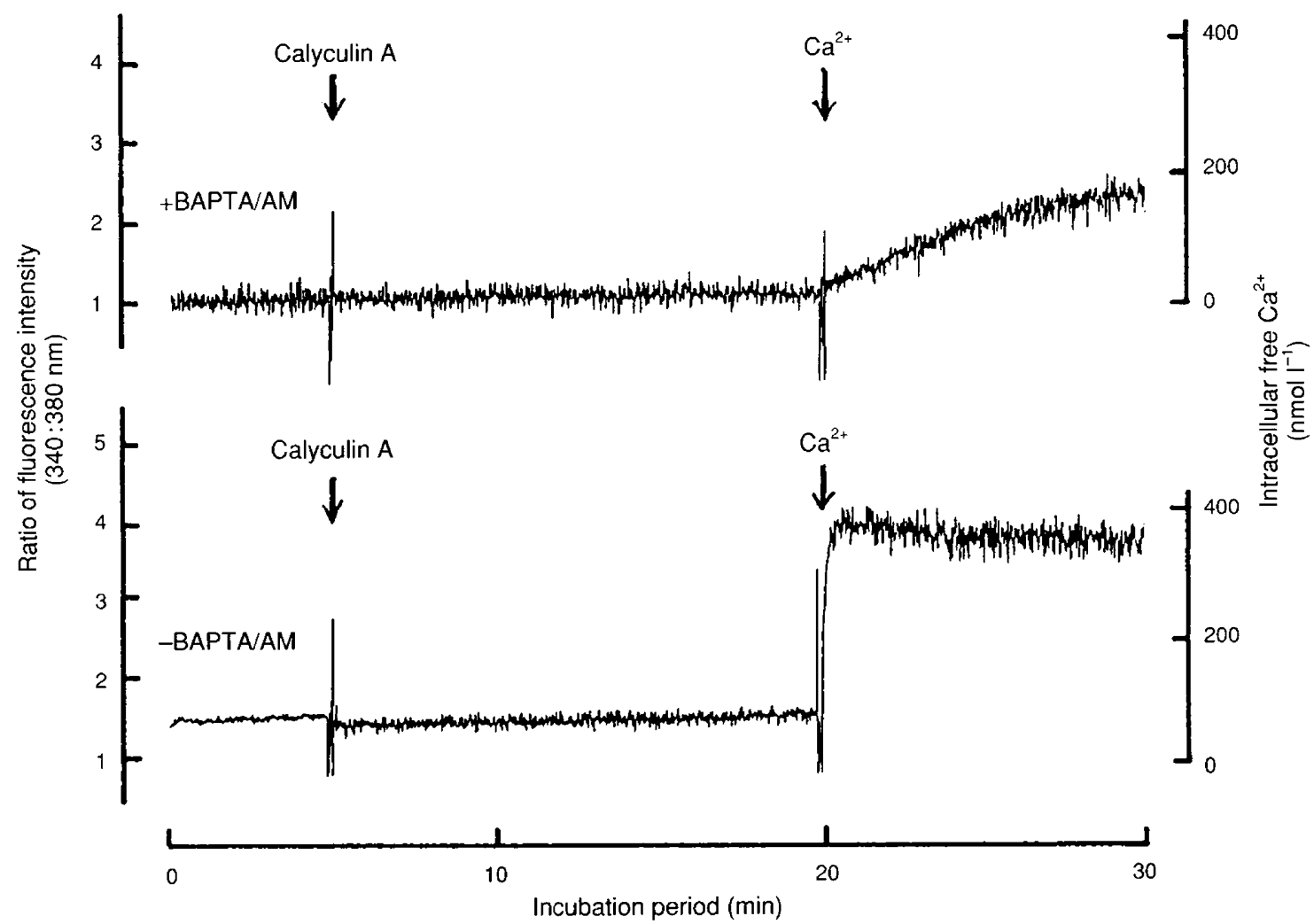

Fig. 3. Changes of intracellular free $\mathrm{Ca}^{2+}$ concentrations in intact fowl spermatozoa (a) with or without calyculin $\mathrm{A}$ at $40^{\circ} \mathrm{C}$, and (b) with or without BAPTA/AM at $40^{\circ} \mathrm{C}$, measured by means of a fluorescent $\mathrm{Ca}^{2+}$ indicator Fura- 2 . Arrows indicate the addition of $2 \mathrm{mmol} \mathrm{CaCl}_{2} \mathrm{l}^{-1}$ and $500 \mathrm{nmol}$ calyculin $\mathrm{A}^{-1}$. 
The authors thank G. J. Wishart, University of Abertay Dundee, for kindly reviewing the manuscript. This study was supported by a Grant-in-Aid for Scientific Research from the Ito Memorial Foundation and by a grant from the Ministry of Education, Science and Culture, Japan (No. 06660360)

\section{References}

Ashizawa K and Nishiyama H (1978) Effects of temperature on the vigour of motility, oxygen consumption and duration of motility of fowl spermatozoa under aerobic conditions Japanese Poultry Science 15 264-266

Ashizawa K and Okauchi K (1984) Stimulation of sperm motility and oxygen consumption of fowl spermatozoa by a low molecular weight fraction of seminal plasma Journal of Reproduction and Fertility 71 593-598

Ashizawa K and Wishart GJ (1987) Resolution of the sperm motility-stimulating principle of fowl seminal plasma into $\mathrm{Ca}^{2+}$ and an unidentified low molecular weight factor Journal of Reproduction and Fertility 81 495-499

Ashizawa K and Wishart GJ (1992) Factors from fluid of the ovarian pocket that stimulate sperm motility in domestic hens Journal of Reproduction and Fertility $95855-860$

Ashizawa K, Maeda S and Okauchi K (1989a) The mechanisms of reversible immobilization of fowl spermatozoa at body temperature fournal of Reproduction and Fertility 86 27I-276

Ashizawa K, Suzuki Y and Okauchi K (1989b) Flagellar movement in demembranated preparations of ejaculated fowl spermatozoa Journal of Reproduction and Fertility $86263-270$

Ashizawa K, Katayama S and Tsuzuki Y (1992a) Regulation of flagellar motility by temperature-dependent phosphorylation of a $43 \mathrm{kDa}$ axonemal protein in fowl spermatozoa Biochemical and Biophysical Research Communications 185 740-745

Ashizawa K, Hashiguchi A and Tsuzuki Y (1992b) Intracellular free $\mathrm{Ca}^{2+}$ concentration in fowl spermatozoa and its relationship with motility and respiration in spermatozoa Journal of Reproduction and Fertility 96 395-405

Ashizawa K, Wishart GJ, Tomonaga H, Nishinakama K and Tsuzuki Y (1994a) Presence of protein phosphatase type 1 and its involvement in temperaturedependent flagellar movement of fowl spermatozoa FEBS Leffers $\mathbf{3 5 0}$ 130-134

Ashizawa K, Tomonaga $\mathrm{H}$ and Tsuzuki $Y$ (1994b) Regulation of flagellar motility of fowl spermatozoa: evidence for the involvement of intracellular free $\mathrm{Ca}^{2+}$ and calmodulin Journal of Reproduction and Feritity $101265-272$

Bakst MR (1987) Anatomical basis of sperm-storage in the avian oviduct Scanning Microscopy 1 1257-1266

Bogdonoff PD Jr and Shaffner CS (1954) The effect of $\mathrm{pH}$ on in vitro survival, metabolic activity, and fertilizing capacity of chicken semen Pouliry Science $33665-669$

Brokaw CJ (1987) Regulation of sperm flagellar motility by calcium and cAMP-dependent phosphorylation Journal of Cellular Biochemistry $\mathbf{3 5}$ $175-184$

Cohen P (1989) The structure and regulation of protein phosphatases Annual Review of Biochemistry $\mathbf{5 8} 453-508$

Cohen P. Holmes CFB and Tsukitani Y (1990) Okadaic acid: a new probe for the study of cellular regulation Trends in Biochemical Sciences 15 98-102

Furuya S, Endo Y and Osumi K (1993) Calyculin A, protein phosphatase inhibitor, enhances capacitation of human sperm Fertility and Sterility $\mathbf{5 9}$ 216-222

Grynkiewicz G, Poenie M and Tsien RY (1985) A new generation of $\mathrm{Ca}^{2+}$ indicators with greatly improved fluorescence properties Journal of Biological Chemistry 260 3440-3450

Hartshorne DJ, Ishihara H, Karaki H, Ozaki H, Sato K, Hori M and Watabe S (1989) Okadaic acid and calyculin A: effects on smooth muscle systems. In Adoances in Protein Phosphatases Vol. 5 pp 219-231 Eds W Merlevede and J Di Salvo. Leuven University Press, Leuven

Holmes CFB and Boland MP (1993) Inhibitors of protein phosphatase-1 and $-2 \mathrm{~A}$; two of the major serine/threonine protein phosphatases involved in cellular regulation Current Opinion in Structural Biology 3 934-943

Hubbard MJ and Cohen P (1993) On target with a new mechanism for the regulation of protein phosphorylation Trends in Biochemical Sciences 18 $172-177$
Ishihara H, Martin BL, Brautigan DL, Karaki H, Ozaki H, Kato Y, Fusetani N, Watabe S, Hashimoto K, Uemura D and Hartshorne DJ (1989a) Calyculin A and okadaic acid: inhibitors of protein phosphatase activity Biochemical and Biophysical Research Communications 159 871-877

Ishihara H, Ozaki H, Sato K, Hori M, Karaki H, Watabe S, Kato Y, Fusetani N, Hashimoto K, Uemura D and Hartshorne DJ (1989b) Calcium-independent activation of contractile apparatus in smooth muscle by calyculin-A Journal of Pharmacology and Experimental Therapeutics 250 388-396

Katz DF and Overstreet JW (1981) Sperm motility assessment by videomicrography Fertility and Sterility 35 188-193

Kielley WW (1963) Preparation and assay of phosphorylating submitochondrial particles: sonicated mitochondria Methods in Enzymology 6 272-277

Klumpp S, Cohen P and Schultz JE (1990) Okadaic acid, an inhibitor of protein phosphatase $\mathrm{I}$ in Paramecium, causes sustained $\mathrm{Ca}^{2+}$-dependent backward swimming in response to depolarizing stimuli EMBO Journal 9 685-689

Lindemann CB and Kanous KS (1989) Regulation of mammalian sperm motility Archives of Andrology 23 1-22

Majumder GC, Dey CS, Haldar S and Barua M (1990) Biochemical parameters of initiation and regulation of sperm motility Archives of Andrology 24 287-303

Mimura H (1939) On the mechanism of travel of spermatozoa through the oviduct in the domestic fowl, with special reference to artificial insemination Okajimas Folia Anatomica Japonica 17 459-476

Mohri H (1993) Role of tubulin and dynein in spermatozoan motility Molecular Reproduction and Development 36 221-223

Morisawa M (1994) Cell signaling mechanisms for sperm motility Zoological Science 11 647-662

Munro SS (1938) Fowl sperm immobilization by a temperature media interaction and its biological significance Quarterly Journal of Experimental Physiology 27 281-287

Ozaki H, Ishihara H, Kohama K, Nonomura Y, Shibata S and Karaki H (1987a) Calcium-independent phosphorylation of smooth muscle myosin light chain by okadaic acid isolated from black sponge (Halichondria okadai) Journal of Pharmacology and Experimental Therapeutics 243 1167-1173

Ozaki H, Kohama K, Nonomura Y, Shibata S and Karaki H (1987b) Direct activation by okadaic acid of the contractile elements in the smooth muscle of guinea-pig Taenia coli Naunyn-Schmiedeburg's Archives of Pharmacology $335356-358$

Suzuki A and Itoh T (1993) Effects of calyculin A on tension and myosin phosphorylation in skinned smooth muscle of the rabbit mesenteric artery British Journal of Pharmacology 109 703-712

Takai A, Bialojan C, Troschka M and Ruegg JC (1987) Smooth muscle myosin phosphatase inhibition and force enhancement by black sponge toxin FEBS Letters 217 81-84

Takeda A (1974) The transport of spermatozoa in the vagina of the hen Japanese Poultry Science 11 45-54

Takeda A (1982) Studies on reversible inactivation of cock spermatozoa by temperature. I. Effects of several factors on reversible inactivation Japanese Poultry Science 19 26-36

Tash JS and Means AR (1983) Cyclic adenosine 3',5' monophosphate, calcium and protein phosphorylation in flagellar motility Biology of Reproduction $\mathbf{2 8}$ $75-104$

Terada T, Watanabe M and Tsutsumi Y (1984) Possible significance of accessory reproductive fluid in the exhibition of fertilizing ability of spermatozoa in the domestic fowl Japanese Joumal of Zootechnical Science 55 52-58

Thomson MF and Wishart GJ (1989) Elucidation of the mechanism responsible for the temperature-dependent reversible inactivation of the motility of fowl spermatozoa British Poultry Science 30 687-692

Thomson MF and Wishart GJ (1991) Temperature-mediated regulation of calcium flux and motility in fowl spermatozoa Journal of Reproduction and Fertility 93 385-391

Wishart GJ (1982) Maintenance of ATP concentrations in and of fertilizing ability of fowl and turkey spermatozoa in vitro Journal of Reproduction and Fertility 66 457-462

Wishart GJ and Ashizawa K (1987) Regulation of the motility of fowl spermatozoa by calcium and cAMP Journul of Reproduction and Fertility 80 607-611

Wishart GJ and Ross FH (1985) Characterization of a spectrophotometric technique for the estimation of fowl and turkey sperm motility Gamete Research 11 169-178 